\title{
FINANCIAL INTEGRATION AND CAPITAL ACCUMULATION IN THE FRANC ZONE
}

\author{
${ }^{*}, 1$ BALLA MEKONGO Célestin Ghislain, ${ }^{2}$ ABBA YADOU Barnabé \\ ${ }^{1,2}$ Laboratory of Research in Fundamental and Applied Economics (LARFAE), University of Dschang \\ *Corresponding author
}

DOI: 10.46609/IJSSER.2020.v05i07.004 URL: https://doi.org/10.46609/IJSSER.2020.v05i07.004

\begin{abstract}
This paper provides original econometric evidence on whether financial integration stimulates capital accumulation based on data for a sample of 15 Franc area countries over the period 19962018. Using the system generalized method of moments, the FMOLS cointegration approach, two main results are found. First, financial integration contributes to capital accumulation in Franc area countries. Second, the effects differ according to the indicators of financial integration. Thus, the Lane and Milesi-Ferretti index reports a higher effect of financial integration on capital accumulation, then comes FDI and finally remittances from migrants over the long run. Our findings suggest that the effect of financial integration on accumulation depends on the indicator used and integration into international financial markets significantly increases the capital stock.
\end{abstract}

Keywords: Financial integration, Capital accumulation, Franc zone, GMM, FMOLS

\section{INTRODUCTION}

The member countries of the Franc zone are becoming increasingly integrated into the international financial markets. As a result of globalisation, the financial repercussions seem to be having a considerable impact on economic activity in the Franc area countries. The existence of the zone's two regional financial markets may constitute an important signal with a view to substantially attracting international savings to the sub-region.

Financial Integration (FI) is a process whereby the financial markets of neighbouring, regional or global economies are closely interlinked - for example, through cross-border capital flows, foreign participation in domestic financial markets and information sharing among financial institutions (Baele et al., 2004; Bekaert et al., 2011). The integration of financial markets produces several benefits to countries' economic development, including the possibility of 


\section{International Journal of Social Science and Economic Research}

ISSN: $2455-8834$

Volume: 05, Issue: 07 "July 2020"

foreign ownership of capital shares in domestic financial institutions by foreign financial institutions, which can promote financial development in a given country, since it increases competition in domestic banking and financial markets (Mishkin, 2009).

The success of the FI requires the fulfilment of a number of conditions. To this extent, the literature generally identifies five major constraints: (i) reforming the domestic financial sector; (ii) monitoring a sound macroeconomic policy that ensures economic stability (fiscal policy, monetary policy, and exchange rate policy); (iii) achieving current account liberalization; (iv) strengthening financial regulation, supervision, and prudential oversight of the financial system; and (v) having an adequate legal system, in particular preparing an appropriate institutional and policy environment to address the risks of unimpeded capital mobility between countries (Eichengreen and Mussa, 1998). However, with resource-rent economies coupled with the absence of a unified, broad and deep capital market, Franc area countries benefit greatly from capital from international financial markets. As a result, they are much further advanced in international financial integration (IFI).

According to data from the IMF's International Financial Statistics (2018), the IFI as measured by the Lane and Milesi-Ferretti index $(2007,2017)$ decreased from 1996 to 2018 in the Franc area from 1.22 to 1.05. On the other hand, FDI inflows as a percentage of GDP decreased from 11.22 to 4.61 from 1996 to 2018, while migrant remittances as a percentage of GDP increased from 1.6 to 3.89 over the same period. It is generally accepted that FIs contribute to economic growth (Bekaert et al., 2011; Allegret and Azzabi, 2014; Ahmed, 2016) through capital accumulation and factor productivity (Bonfiglioli, 2008; Bekaert et al., 2011; Ekpo and Chuku, 2017).

While the contribution of the FI has been analysed in more depth in terms of economic development, its effect appears to be less captured indirectly on capital accumulation. Indeed, the capital stock in the Franc area is increasing despite the strong constraints on local entrepreneurs ${ }^{1}$. The growth rate of the capital stock increased from 3.64\% to 4.63\% between 1996 and 2018 . According to AfDB forecasts (2018), the private sector in the Franc zone must benefit from innovative financing to ensure strong growth in the long term.

Considering a correlated increase in the FI index and the capital stock in the Franc area on the one hand and the scarcity of work linking these two key variables of modern country development on the other, this study aims to examine the contribution of the FI on capital accumulation in the Franc area. Furthermore, it compares the effect of different measures of FI on capital accumulation. This objective draws on recent literature in the field of study and uses

${ }^{1}$ Factor costs, bank under-financing, lack of energy, scarcity of physical infrastructure among others, limit the real acceleration of domestic private investment. 


\section{International Journal of Social Science and Economic Research}

ISSN: $2455-8834$

Volume: 05, Issue: 07 "July 2020"

appropriate econometric techniques (Bonfiglioli, 2008; Lane and Milesi-Ferretti, 2017) to empirically establish this relationship. The main interest of the study is to show the differentiated effects of FI measures on capital accumulation in the Franc area.

The authors make two major contributions to existing work. On the one hand, they highlight the importance of taking into account a wide range of FI measurement indicators in order to assess their indirect effects on growth, notably through capital accumulation. On the other hand, the authors study this relationship on a sample of developing countries, particularly African countries from a sub-region that experiences huge differences in regional integration.

Following this introduction, the rest of the article is organized as follows. The second section is devoted to a review of the literature. The third section presents the empirical methodology while the fourth section provides an analysis of the data and descriptive statistics. The fifth and sixth sections discuss the empirical results and robustness check, respectively. The final section of the paper presents the conclusion.

\section{LITERATURE REVIEW}

There is an extensive literature on the benefits of FI for the economic growth of recipient countries that dates back to the 20th century. The work of McKinnon (1973) and Shaw (1973) demonstrated that financial liberalization, particularly external financial liberalization, contributes to increased economic activity. From then on, financial openness became a determining factor in economic growth and justified the differences in wealth observed between countries (Barro et al., 1992). This analysis has helped to explain the lag observed between developed and developing countries. Specifically, the effect of financial integration on economic growth is based on two main channels (Gaies, 2018).

The first is to directly affect the rate of capital accumulation. Indeed, FIs can contribute to economic growth by alleviating the financial constraints of households and increasing the level of investment in the economy. Indeed, since capital is relatively scarce in developing countries, the marginal return on capital is also higher, implying that international savings will migrate to developing countries (Romer, 1986). The abundance of external capital flows will thus make it possible to meet the economy's financing needs and improve domestic consumption (Levy, 1988; Obstfeld, 1998).

The second channel is productivity growth. Regarded as a modern approach to the effect of the FI on economic growth, this channel demonstrates that the indirect or collateral growth gains generated by the FI through an increase in factor productivity are much greater than those associated with capital accumulation and allocation (Gourinchas and Jeanne, 2006; Kose et al., 2009). Indeed, FIs help to strengthen the structure of economies through the development of the 
International Journal of Social Science and Economic Research

ISSN: $2455-8834$

Volume: 05, Issue: 07 "July 2020"

financial system (Rajan and Zingales, 1998; Allegret and Azzabi, 2014; Ahmed, 2016), the efficient specialization of the productive apparatus (Bekaert et al., 2006; Islamaj, 2014) and the quality of institutions (Rodrik and Subramanian, 2003; Kose et al., 2009). However, for developing countries, the contribution of FIs to capital accumulation remains an important factor because of the infrastructure deficit and low diversification of the productive base (Ahmed and Mmolainyane, 2014).

Indeed, the debate on the impact of the FI on capital accumulation is at the heart of empirical debates. Bonfiglioli's (2008) work has shown that the effect of FIs on capital accumulation is negative or even non-existent in Africa while the effect is positive for Latin American countries. Following this work, Bekaert et al (2011) will show that financial openness improves productivity, in particular by promoting capital accumulation in advanced and emerging countries. However, Mougani (2012) insists on the dangers of FIs because, for this author, financial openness increases the volatility of economic growth in Africa. These authors generally use the index of Lane and Milesi-Feretti $(2007,2017)$ as a measure of the FI. However, a new lease of life will come with the study by Ekpo and Chuku (2017) who will in turn show that the interconnection of regional financial markets improves capital accumulation and de facto economic activity growth in Africa.

Our study builds on Bonfiglioli's (2008) analysis by considering other FI measures and their impact on capital accumulation following the logic developed by Eggoh et al, (2019) in the context of external financing.

\section{EMPIRICAL METHODOLOGY}

Our empirical strategy is based on two estimation techniques: the system generalized method of moments (GMM) and the FMOLS2 cointegration approach on dynamic panel data. The GMMin-system estimator allows us to establish the direct relationship between the FI and capital stock growth, while the FMOLS estimator highlights the long-run relationship based on a cointegration approach. This estimator tests the robustness of the GMM results.

\subsection{System GMM specification}

In order to properly test the hypothesis that FIs can affect capital accumulation, we use the dynamic panel data estimator (GMM in system) as developed by Holtz-Eakin, Newey and Rosen (1988), Arellano and Bond (1991), Arellano and Bover (1995), and Blundell and Bond (1998) to estimate our capital accumulation model. The system GMM estimator consists of stacked level and difference regressions.

The system GMM specification of our basic model is as follows: 
International Journal of Social Science and Economic Research

ISSN: $2455-8834$

Volume: 05, Issue: 07 "July 2020"

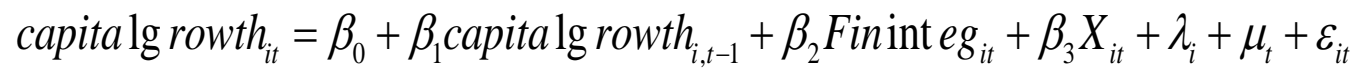

Where capital growth represents the growth rate of the capital stock (constant 2011 US dollars), our main variable of interest is Fininteg, which represents the variables that capture the importance of each indicator contributing to the interconnectedness of the international financial systems. These are the Lane and Milesi-Ferretti index (2007, 2017), Foreign Direct Investment and migrant remittances. $X$ represents a vector of control variables whose objective is to take into account other factors associated with capital accumulation, $\lambda \mathrm{i}$ is a country-specific unobserved effect, $\mu$ t is time-specific and $\varepsilon i t$ is the error term. By incorporating the financial integration variables into equation (1), we can rewrite it as follows:

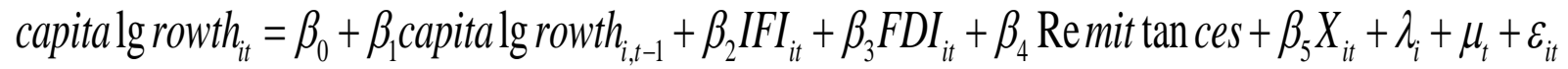

While in the difference GMM model, the lagged levels of the exogenous variables are used as instruments, the system GMM estimator uses the lagged differences of the explanatory variables as instruments for the level equations, in addition to the lagged levels of the explanatory variables as instruments for the first difference equations. This model has been widely used to solve the endogeneity problem that arises in estimating growth regressions from panel data (Arellano and Bover 1995; Blundell and Bond 1998). It also takes into account the biases that appear due to country-specific effects (Eggoh et al., 2019). Finally, as indicated in the abovementioned studies, the system generalised method of moments also avoids problems of simultaneous or inverse causality. Two diagnostic tests are performed to check the consistency of the GMM estimator in system: the Hansen's test for the over identification of restrictions in which the null hypothesis considers that the instruments are uncorrelated with the residuals, and the Arellano-Bond test for the second-order correlation in the first-difference residuals. However, in order to truly establish a cointegration approach to illustrate the long-run relationship between FI and capital accumulation, we use the panel FMOLS estimator.

\subsection{Robustness tests: Panel FMOLS cointegration estimate}

The GMM system estimator does not take into account the fact that the panel may be cointegrated. Therefore, we estimate the long-term relationship using the fully modified OLS (FMOLS) panel approach proposed by Pedroni (2000, 2001). The FMOLS estimator not only generates consistent estimates over small samples, but also controls for the likely endogeneity of the regressors and the serial correlation. This estimator provides the long-term relationship following the panel FMOLS estimator. 
International Journal of Social Science and Economic Research

ISSN: $2455-8834$

Volume: 05, Issue: 07 "July 2020"

\section{DATA AND DESCRIPTIVE STATISTICS}

This study covers the period 1996 to 2018 and focuses on data for a sample of 15 developing countries and Franc zone members ${ }^{2}$, based on data quality and availability. Indeed, there is a broad consensus in the literature that the quality of data on financial integration is extremely poor, especially over a long period of time (Kose et al., 2009; Gaies, 2019). As a result, efforts to measure financial integration suffer from important limitations because official estimates do not take into account all components of financial globalization (Chen and Quang, 2014; Steiner, 2018). Data are taken from the "External Wealth of Nations mark II database" (Lane and MilesiFerretti, 2007, 2017) and the World Development Indicators (WDI, 2018).

Our endogenous variable is the growth of capital stock per capita (in constant 2011 US dollars) available in Penn World Table 9.1 and the main exogenous variables are the IFI-rated Lane and Milesi-Ferretti $(2007,2017)$ index, net inflows of foreign direct investment and migrant remittances. These variables make it possible to capture the integration of Franc area countries into international financial markets. The Lane and Milesi-Ferretti $(2007,2017)$ index is a de facto measure of financial openness based on quantities ${ }^{3}$. FDI measures equity stakes in the capital of domestic companies above 50\%. Data on FDI are available in WDI (2018). Migrant remittances refer to current transfers in cash or in kind made by migrants and include personal transfers and compensation of employees. Personal transfers include all current transfers in cash or in kind made (or received) by resident households to (or from) non-resident households ${ }^{4}$.

Following empirical work on the determinants of growth, we use a set of variables that control the level of capital accumulation to assess the strength of an independent link between financial integration and capital accumulation. To capture financial depth, we use domestic credit provided by the banking sector as a percentage of GDP (Credit). We use the rate of inflation (Inflation) as an indicator of macroeconomic stability and the sum of exports and imports of goods and services (Openness) as a percentage of GDP to capture the degree of openness of an economy. The private investment ratio (PIR) is measured as the ratio of gross fixed capital formation to GDP. Moreover, in order to integrate the characteristics of the productive base of the CFA zone countries, we use the total rent on natural resources as a percentage of GDP. Following the studies on the role of institutions on economic activity (Rodrik and Subramanian, 2003), we integrate the Polity 2 measure of democracy. To avoid the influence of idiosyncratic economic dynamics at the frequency of the business cycle, as well as to control for cyclical movements in production, we use 4-year interval averages (except for the last period for which

\footnotetext{
${ }^{2}$ Benin, Burkina-Faso, Cameroon, Central African Republic, Chad, Comoros, Congo Republic, Ivory-Coast, Equatorial Guinea, Gabon, Guinea-Bissau, Mali, Niger, Senegal, Togo.

${ }^{3}$ It is calculated as the sum of external assets and liabilities over GDP.

${ }^{4}$ Data on remittances are available on WDI (2018).
} 
International Journal of Social Science and Economic Research

ISSN: $2455-8834$

Volume: 05, Issue: 07 "July 2020"

we average 3 -year data $)^{5}$. The results of this study are presented in the following table. Table 1 provides descriptive statistics on the variables used. Descriptions of the data are provided in Table A.1.

Over the period 1996-2018, descriptive statistics show that capital stock growth is higher in the countries under consideration (6,304). The IFI index is lower than the average level of remittances relative to GDP is 3.30 , which is itself slightly lower than the ratio of net inflows of foreign direct investment to GDP (4.191). The importance of FDI in the Franc area remains dependent on the exploitation of natural resources and agricultural products. With regard to the control variables, we can note that financial development, inflation, private investment, total rent on natural resources are low while the degree of trade openness is high.

Table 1: Summaries statistics

\begin{tabular}{lccccc}
\hline & Observations & Mean & Std. Dev. & Minimum & Maximum \\
\hline Capitalgrowth & & & & & \\
IFI & 330 & 5,545 & 6,304 & $-14,343$ & 36,894 \\
FDI & 337 & 1,100 & 0,766 & $-0,790$ & 3,606 \\
Remittances & 345 & 4,191 & 11,852 & $-8,703$ & 161,824 \\
Credit & 269 & 3,305 & 3,401 & 0,039 & 13,921 \\
Openness & 345 & 12,138 & 7,381 & 0,403 & 41,156 \\
Inflation & 336 & 67,296 & 29,121 & 30,733 & 165,646 \\
GFCF & 317 & 3,221 & 5,755 & $-8,975$ & 50,734 \\
Totalrent & 319 & 13,827 & 6,792 & 1,455 & 49,594 \\
Polity & 326 & 15,639 & 14,850 & 1,236 & 84,240 \\
\hline
\end{tabular}

Benin, Burkina-Faso, Cameroon, Central African Republic, Chad, Comoros, Congo Republic, Ivory-Coast, Equatorial Guinea, Gabon, Guinea-Bissau, Mali, Niger, Senegal, Togo

Source : Authors.

Table A.2 in the Appendix presents the correlation matrix of the variables selected in this study. We can see that the correlation between the different variables is low. In addition, Table A.3 presents the unit root tests of Maddala and Wu (1999) and Im, Pesaran and Shin (2003) and shows that some variables are stationary in level and others are stationary when put in first difference. Table A.4 presents the cointegration tests of Pedroni (2004) and Westelund and Edgerton (2007). The results show that our panel is cointegrated. With the data and descriptive statistics thus presented, we can proceed to the empirical results of the basic model.

${ }^{5}$ Beck, Levine et Loayza, 2000 


\section{EMPIRICAL RESULTS}

Indeed, we analyze the impact of the FI on capital accumulation. To do so, we compare the effect on capital accumulation of the different measures of the FI, namely the Lane and Milesi-Ferretti index $(2007,2017)$, foreign direct investment and migrant remittances for Franc zone member countries. The results obtained from the basic dynamic panel model (Eq. 2) following the GMM system estimator are presented in Table 2 .

To alleviate concerns about endogeneity, we have delayed all regressors by one period. In all regressions in Table 2, we control for the share of investment in GDP, domestic credit to the private sector as a percentage of GDP, the share of trade (exports and imports) in GDP, the rate of inflation, the share of total resource rent in GDP, and the democracy indicator. The regressions satisfy the specification tests (AR1, AR2 and Hansen tests). There is no evidence of a second serial correlation, but there is strong evidence of a first serial correlation. In addition, the regressions pass the Hansen test and confirm the validity of the instruments.

Table 2: Résultat GMM de l'impact de l'IF sur le stock du capital

\begin{tabular}{|c|c|c|c|}
\hline & \multicolumn{3}{|c|}{ Dependent variables : Capital stock growth } \\
\hline & IFI & FDI & Remittances \\
\hline \multirow[t]{2}{*}{ L.capitalgrowth } & $0.419 * * *$ & $0.334 * * *$ & $0.357 * * *$ \\
\hline & $(0.0920)$ & $(0.0432)$ & $(0.0723)$ \\
\hline \multirow[t]{2}{*}{ Fininteg } & 4.020* & $0.303 * *$ & $0.279 *$ \\
\hline & $(2.269)$ & $(\mathbf{0 . 1 3 0})$ & $(0.457)$ \\
\hline \multirow[t]{2}{*}{ GFCF } & $0.282 *$ & $0.00982 *$ & 0.641 \\
\hline & $(0.181)$ & $(0.123)$ & $(0.494)$ \\
\hline \multirow[t]{2}{*}{ Credit } & $-0.127 * *$ & -0.0401 & $-0.0174 *$ \\
\hline & $(0.0562)$ & $(0.0553)$ & $(0.0910)$ \\
\hline \multirow[t]{2}{*}{ Openness } & $0.134 *$ & 0.00539 & 0.0176 \\
\hline & $(0.0743)$ & $(0.0401)$ & $(0.0636)$ \\
\hline \multirow[t]{2}{*}{ Inflation } & -0.0923 & $-0.203 * * *$ & -0.395 \\
\hline & $(0.0872)$ & $(0.0372)$ & $(0.639)$ \\
\hline \multirow[t]{2}{*}{ Rent } & $-0.207^{*}$ & $-0.0232 *$ & $-0.0327 * *$ \\
\hline & $(0.103)$ & $(0.0617)$ & $(0.122)$ \\
\hline \multirow[t]{2}{*}{ polity2 } & $0.0136^{*}$ & $0.112 * * *$ & $0.469 * *$ \\
\hline & $(0.157)$ & $(0.145)$ & $(0.187)$ \\
\hline \multirow[t]{2}{*}{ Constant } & 3.303 & $5.097 * *$ & 15.70 \\
\hline & (2.371) & (2.189) & (11.42) \\
\hline
\end{tabular}


International Journal of Social Science and Economic Research

ISSN: $2455-8834$

Volume: 05, Issue: 07 "July 2020"

$\begin{array}{lccc}\text { Observations } & 70 & 71 & 57 \\ \text { Number of countries } & 15 & 15 & 15 \\ \text { Instruments } & 14 & 14 & 14 \\ \text { ar1p } & 0.0140 & 0.0134 & 0.074 \\ \text { ar2p } & 0.134 & 0.123 & 0.0497 \\ \text { Hansen OIR } & 0.706 & 0.655 & 0.580\end{array}$

Notes: Heteroskedasticity robust standard deviations are shown. in brackets, 2) *,**, and *** indicate significativité at 10\%, 5\%. and $1 \%$ respectively; 3 ) the Arellano and Bond (AR2) statistic tests for the null hypothesis of second order non-correlation of residuals, 4) Hansen's statistic tests the hypothesis of non-correlation between the instruments and residues

Source : Authors

On the basis of the estimates, the FI variables are positively and significantly related to capital accumulation. This result supports the idea that FIs stimulate capital accumulation in developing countries and corroborates the results of Ekpo and Chuku (2017) but contrasts with the work of Bonfiglioli (2008) who finds a negative impact of financial integration on capital accumulation in Africa, particularly using the IFI index. Regarding the effect of other variables capturing the IF, we find that the coefficients associated with net FDI inflows and remittances are positive and significant but lower than the IFI coefficient. It shows that FDI and migrant remittances seem to be correlated with capital accumulation in Franc zone countries, which allows them to contribute to economic growth, following the example of Nyamongo et al (2012), Adams and Opoku (2015), Nwaogu and Ryan (2015), OngoNkoa (2018). This result makes it possible, for a short time, to clear up the debate on the effectiveness of external financing (FDI and migrant remittances) and to question the criticisms that are generally made of the conditions under which this external financing reaches Africa: exploitation of natural resources, relations between the former colonies and their metropolis and political instability. In this perspective, FDI would not contribute directly to improving the quality of life but the exploitation of natural resources and capital flight. On the other hand, migrant remittances would generally increase with periods of political crisis (Fayissa and Nsiah, 2010). However, the results do indeed suggest that the FI positively affects capital accumulation through a massive inflow of external financing following the traditional view of the impact of financial openness on economic activity (Gaies, 2018).

Consider a general comment on the other control variables. All explanatory variables have the expected sign. Indeed, as expected, the results confirm that the investment variable is positively associated with capital accumulation, as predicted by Solow's growth model: its positive sign reflects the growing relationship between private investment and capital accumulation (see Barro 


\section{International Journal of Social Science and Economic Research}

ISSN: $2455-8834$

Volume: 05, Issue: 07 "July 2020"

et al., 1992; Aghion and Howitt, 2008). Financial development captured by domestic credit to the private sector has a significant negative effect on capital accumulation, showing that the banking sector is not sufficiently supportive of the private sector (Assefa and Mollick, 2017). Trade openness relative to GDP has a positive effect on capital accumulation, which is consistent with both the neoclassical approach and endogenous growth theory. Indeed, according to the former, the positive impact of trade on capital accumulation is explained by comparative advantages, while the literature on endogenous growth argues that trade openness positively affects capital accumulation through economies of scale and technology diffusion between countries. The role of inflation in slowing capital accumulation is also investigated. The estimated coefficient is negative and significant, suggesting a negative effect of inflation on capital accumulation. This result supports the traditional view that higher economic growth cannot be achieved in a context of low and stable inflation. The sign of the variable capturing the total resource rent is negative and significant. This result demonstrates that resource rents negatively affect capital accumulation to the extent that income from resource rents is not reinvested in the productive system (Aregha and Mesagan, 2016). Finally, the role of the quality of institutions on capital accumulation is highlighted using the Polity2 variable. With a positive and significant sign, the democratic system makes optimal the conditions for economic activity, which favours capital accumulation (Teles, 2007; Valeriani and Peluso, 2011). However, since the GMM system estimator does not take into account cointegration in panel data, the FMOLS approach allows to remedy this by consolidating the existence of a long-term relationship.

\section{ROBUSTNESS CHECK}

To further assess the robustness of the estimates capturing the relationship between financial integration and capital accumulation, we conducted regressions following the GMM system estimator on dynamic panel data. This estimator goes beyond these traditionally accepted qualities to provide long-run results. However, to better investigate this relationship, we use a cointegration approach following the panel FMOLS estimator. The estimation results are presented in Table 3.

Table 3: FMOLS estimate of FI impact on capital accumulation

\begin{tabular}{lccc}
\hline \multirow{2}{*}{ Fininteg } & \multicolumn{3}{c}{ Dependent variables : Capital stock growth } \\
\cline { 2 - 4 } & IFI & FDI & Remittances \\
\hline \multirow{2}{*}{ GFCF } & $\mathbf{3 . 3 0 0 * * *}$ & $\mathbf{0 . 5 6 5 * * *}$ & $\mathbf{0 . 2 3 9 * *}$ \\
& $(\mathbf{3 . 7 7 8 )}$ & $(\mathbf{6 . 8 1 3 )}$ & $\mathbf{( 2 . 7 2 1 )}$ \\
& $0.146^{*}$ & $0.4239 * * *$ & $0.257 * * *$ \\
& $(2.123)$ & $(7.942)$ & $(4.174)$
\end{tabular}


International Journal of Social Science and Economic Research

ISSN: $2455-8834$

Volume: 05, Issue: 07 "July 2020"

\begin{tabular}{lccc} 
Credit & $-0.127 *$ & $-0.234^{* * *}$ & $-0.338^{* *}$ \\
& $(0.248)$ & $(-2.730)$ & $(-3.724)$ \\
Openness & $0.1052^{* *}$ & $0.2057 * * *$ & 0.0607 \\
& $(2.99)$ & $(4.939)$ & $(1.682)$ \\
Inflation & -0.14569 & $-0.094^{*}$ & $-0.202^{* * *}$ \\
& $(3.419)$ & $(-1.896)$ & $(-4.146)$ \\
Rent & $-0.233^{* *}$ & $-0.4614^{* * *}$ & $-0.2548^{* *}$ \\
& $(2.449)$ & $(-4.39)$ & $(-2.374)$ \\
polity2 & $0.138^{* * *}$ & 0.0380 & 0.0517 \\
& $(3.835)$ & $(0.814)$ & $(1.027)$ \\
R-squared & 0.80 & 0.88 & 0.77 \\
Adjusted R-squared & 0.69 & 0.82 & 0.65 \\
S.E. of regression & 1.61 & 1.21 & 1.71 \\
\hline
\end{tabular}

Note: The dependent variable is capital stock growth. t-statistics in the parentheses. $* * *, * *, *$ indicatesignificance at $1 \%, 5 \%, 10 \%$ level.

Source: Authors.

Based on the results presented in Table 3, three major facts deserve our attention. First, the results confirm the long-term relationship between the data. As was obtained from the cointegration tests carried out above. Second, we find that the different variables that capture the FI have a positive and significant coefficient. This result shows that the FI improves capital accumulation in the long run. The IFI variable has a higher coefficient than the other IF variables by 3.30 points, suggesting that integration with international financial markets increase capital accumulation (Bonfiglioli, 2008; Bekaert et al., 2011). The other two variables, notably FDI and migrant remittances, also contribute to capital accumulation, with a larger effect observed for FDI (Pegkas, 2015). The coefficients of the control variables are identical to those obtained in table 2. Finally, these results corroborate the long-term predictions made by the results from the GMM in-system estimator.

\section{CONCLUSION}

The objective of this study was to show the impact of the FI on capital accumulation in the Franc area. Using a GMM system model and a cointegration approach following the FMOLS estimator for a dynamic panel of 15 developing countries over the period 1996-2018, we show that the three variables of the FI can favour capital accumulation. Specifically, interconnection with international financial markets generates capital inflows that enable the production apparatus to move more efficiently by facilitating the acquisition of inputs and the realization of $R \& D$ expenditures, thereby increasing the availability of inputs and new knowledge. Among these 
International Journal of Social Science and Economic Research

ISSN: $2455-8834$

Volume: 05, Issue: 07 "July 2020"

three variables, the Lane and Milesi-Ferretti index $(2007,2017)$ has a greater impact on capital accumulation than the others (FDI and remittances). The use of the cointegration approach by the FMOLS estimator confirmed the impact of the FI on long-term capital accumulation. These results satisfy theoretical predictions that financial FIs have an impact on economic growth through capital allocation and accumulation (Obstfeld, 1998; Gaies, 2018).

The main economic policy recommendation is that public authorities should provide an adequate structural framework to direct external financing towards projects that contribute to the expansion of productive activities and facilitate the acquisition of new knowledge through R\&D investments.

\section{REFERENCES}

Adams, S., \& Opoku, E. E. O. (2015). Foreign direct investment, regulations and growth in subSaharan Africa. Economic Analysis and Policy, 47, 48-56.

Afdb. 2018, African economic outlook, African Developement Bank, Abidjan.

Aghion, P., \& Howitt, P. W. (2008). The economics of growth. MIT press.

Ahmed, A. D. (2016). Integration of financial markets, financial development and growth: Is Africa different?. Journal of International Financial Markets, Institutions and Money, 42, 43-59.

Ahmed, A. D., \& Mmolainyane, K. K. (2014). Financial integration, capital market development and economic performance: Empirical evidence from Botswana. Economic Modelling, 42, 1-14.

Allegret, J. P., \& Azzabi, S. (2014). Intégration financière internationale et croissance économique dans les pays émergents et en développement: le canal du développement financier. Revue d'economie du developpement, 22(3), 27-68.

Arellano, M., \& Bond, S. (1991). Some tests of specification for panel data: Monte Carlo evidence and an application to employment equations. The review of economic studies, 58(2), 277-297.

Arellano, M., \& Bover, O. (1995). Another look at the instrumental variable estimation of errorcomponents models. Journal of econometrics, 68(1), 29-51.

Assefa, T. A., \& Mollick, A. V. (2017). Financial development and economic growth in Africa. Journal of African Business, 18(3), 320-339. 


\section{International Journal of Social Science and Economic Research}

ISSN: $2455-8834$

Volume: 05, Issue: 07 "July 2020"

Baele, L., Ferrando, A., Hördahl, P., Krylova, E., \& Monnet, C. (2004). Measuring financial integration in the euro area (No. 14). ECB occasional paper.

Barro, R. J., Mankiw, N. G., \& Sala-i-Martin, X. (1992). Capital mobility in neoclassical models of growth (No. w4206). National Bureau of Economic Research.

Beck, T., Levine, R., \&Loayza, N. (2000). Finance and the Sources of Growth. Journal of financial economics, 58(1-2), 261-300.

Bekaert, G., Harvey, C. R., \& Lundblad, C. (2006). Growth volatility and financial liberalization. Journal of international money and finance, 25(3), 370-403.

Bekaert, G., Harvey, C. R., \& Lundblad, C. (2011). Financial openness and productivity. World Development, 39(1), 1-19.

Blundell, R., \& Bond, S. (1998). Initial conditions and moment restrictions in dynamic panel data models. Journal of econometrics, 87(1), 115-143.

Bonfiglioli, A. (2008). Financial integration, productivity and capital accumulation. Journal of International Economics, 76(2), 337-355.

Chen, J., \& Quang, T. (2014). The impact of international financial integration on economic growth: New evidence on threshold effects. Economic Modelling, 42, 475-489.

Eggoh, J., Bangake, C., \&Semedo, G. (2019). Do remittances spur economic growth? Evidence from developing countries. The Journal of International Trade \& Economic Development, 28(4), 391-418.

Eichengreen, B., \&Mussa, M. (1998). Capital account liberalization and the IMF. Finance and Development, 35, 16-19.

Ekpo, A., \& Chuku, C. (2017). Regional financial integration and economic activity in Africa. Journal of African Economies, 26(suppl_2), ii40-ii75.

Eregha, P. B., \&Mesagan, E. P. (2016). Oil resource abundance, institutions and growth: Evidence from oil producing African countries. Journal of Policy Modeling, 38(3), 603619.

Fayissa, B., \& Nsiah, C. (2010). The impact of remittances on economic growth and development in Africa. The American Economist, 55(2), 92-103.

Gaies, B. (2018). Globalisation financière et croissance dans les pays en développement: mise en évidence des effets sur l'instabilité financière et l'instabilité monétaire (Doctoral dissertation, Paris 10). 


\section{International Journal of Social Science and Economic Research}

ISSN: $2455-8834$

Volume: 05, Issue: 07 "July 2020"

Gourinchas, P. O., \& Jeanne, O. (2006). The elusive gains from international financial integration. The Review of Economic Studies, 73(3), 715-741.

Holtz-Eakin, D., Newey, W., \& Rosen, H. S. (1988). Estimating vector autoregressions with panel data. Econometrica: Journal of the econometric society, 1371-1395.

Im, K. S., Pesaran, M. H., \& Shin, Y. (2003). Testing for unit roots in heterogeneous panels. Journal of econometrics, 115(1), 53-74.

Islamaj, E. (2014). Industrial specialization, financial integration and international consumption risk sharing. The BE Journal of Macroeconomics, 14(1), 477-509.

Kose, M. A., Prasad, E. S., \& Taylor, A. D. (2009). Thresholds in the process of international financial integration. The World Bank.

Lane, P. R., \&Milesi-Ferretti, G. M. (2007). The external wealth of nations mark II: Revised and extended estimates of foreign assets and liabilities, 1970-2004. Journal of international Economics, 73(2), 223-250.

Levy, V. (1988). Aid and growth in Sub-Saharan Africa: The recent experience. European Economic Review, 32(9), 1777-1795.

Maddala, G. S., \& Wu, S. (1999). A comparative study of unit root tests with panel data and a new simple test. Oxford Bulletin of Economics and statistics, 61(S1), 631-652.

Milesi-Ferretti, G. M., \& Lane, P. R. (2017). International financial integration in the aftermath of the global financial crisis. Working Paper 115, International Monetary Fund.

Mishkin, F. S. (2009). Globalization and financial development. Journal of development Economics, 89(2), 164-169.

Mougani, G. (2012). An analysis of the impact of financial integration on economic activity and macroeconomic volatility in Africa within the financial globalization context. African Development Bank Group, Office of the Chief Economist.

Nkoa, B. E. O. (2018). Effets différenciés des IDE sur la croissance économique africaine: le rôle de la finance. Revue d'economie du developpement, 26(3), 33-63.

Nwaogu, U. G., \& Ryan, M. J. (2015). FDI, foreign aid, remittance and economic growth in developing countries. Review of Development Economics, 19(1), 100-115.

Nyamongo, E. M., Misati, R. N., Kipyegon, L., \&Ndirangu, L. (2012). Remittances, financial development and economic growth in Africa. Journal of economics and business, 64(3), 240-260. 


\section{International Journal of Social Science and Economic Research}

ISSN: $2455-8834$

Volume: 05, Issue: 07 "July 2020"

Obstfeld, M. (1998). The global capital market: benefactor or menace?. Journal of economic perspectives, 12(4), 9-30.

Pedroni, P. (2004). Panel cointegration: asymptotic and finite sample properties of pooled time series tests with an application to the PPP hypothesis. Econometric theory, 597-625.

Pegkas, P. (2015). The impact of FDI on economic growth in Eurozone countries. The Journal of Economic Asymmetries, 12(2), 124-132.

Rajan, R., \& Zingales, L. (1998). Financial development and growth. American EconomicReview, 88(3), 559-586.

Rodrik, D., \&Subramanian, A. (2003). La primauté des institutions (ce que cela veut dire et ce que cela ne veut pas dire). Finances etdéveloppement, 31-34.

Romer, P. M. (1986). Increasing returns and long-run growth. Journal of political economy, 94(5), 1002-1037.

Steiner, A. C., \&Saadma, T. (2016). Measuring De Facto Financial Openness: A New Index.

Teles, V. K. (2007). Institutional quality and endogenous economic growth. Journal of Economic Studies.

Valeriani, E., \& Peluso, S. (2011). The impact of institutional quality on economic growth and development: An empirical study. Journal of Knowledge Management, Economics and Information Technology, 1(6), 1-25.

Westerlund, J., \& Edgerton, D. L. (2007). A panel bootstrap cointegration test. Economics letters, 97(3), 185-190.

WGI. 2018. Worldwide governance indicators, The World Bank.

McKinnon, R. I. 1973, Money and capital in economic development, Brookings Institution Press.

Shaw, E. S. 1973, Financial deepening in economic development, Oxford University Press.

Pedroni, P. (2000). Fully modified OLS for heterogeneous cointegrated panels. Advances in econometrics, 15, 93-130.

Pedroni, P. (2001). Purchasing power parity tests in cointegrated panels. Review of Economics and statistics, 83(4), 727-731. 
International Journal of Social Science and Economic Research

ISSN: 2455-8834

Volume: 05, Issue: 07 "July 2020"

\section{ANNEXES}

Table A.1. Description of variables

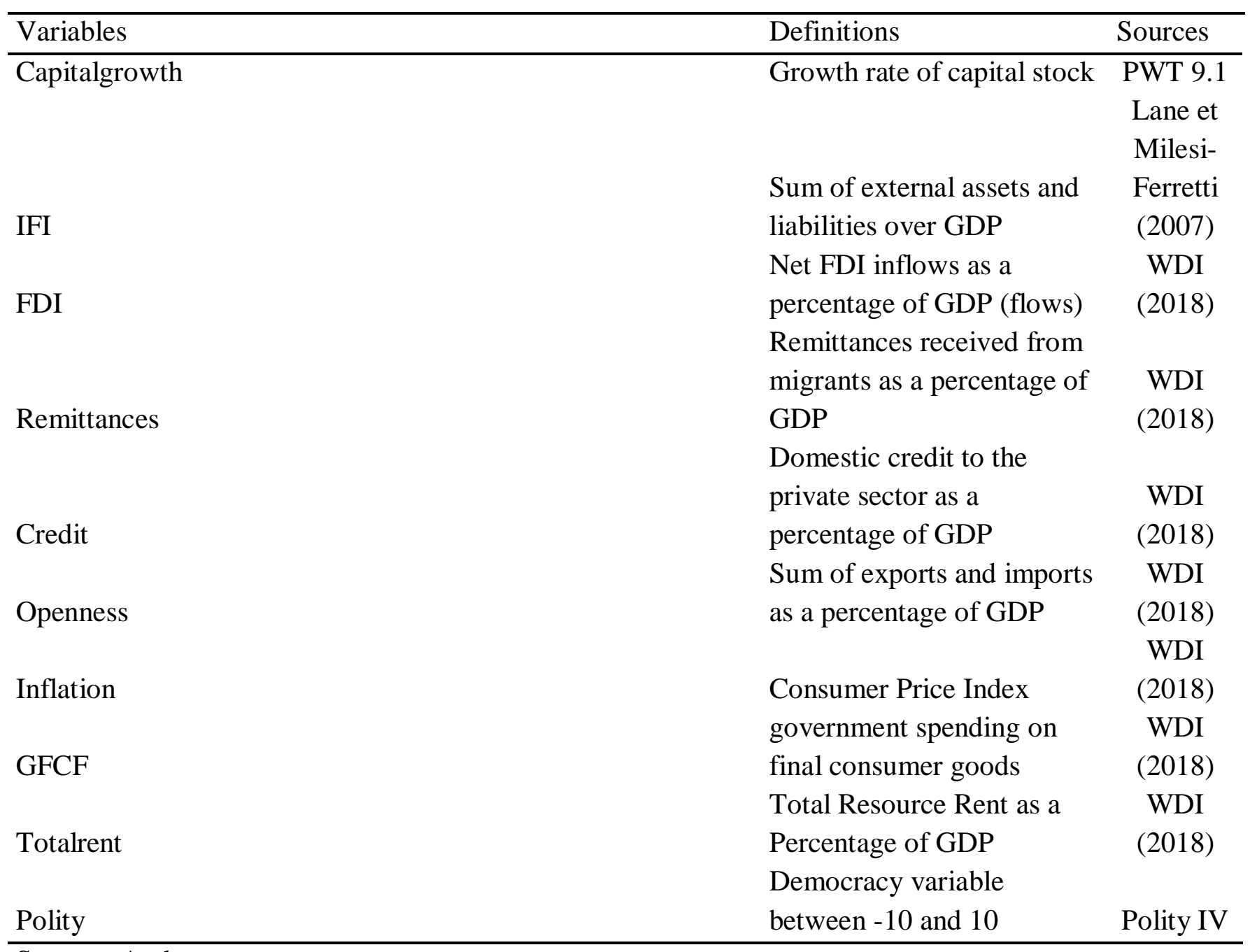

Source : Authors. 
Table A.2. Correlation matrix

\begin{tabular}{|c|c|c|c|c|c|c|c|c|c|c|c|c|c|c|}
\hline & Capitalgrowth & IFI & FDI & Remit & Kaopen & Credit & Openness & Inflation & GFCF & $\mathrm{HCI}$ & Totalrent & Govexp & Corruption & Polity2 \\
\hline Capitalgrowth & 1,000 & & & & & & & & & & & & & \\
\hline IFI & 0,054 & 1,000 & & & & & & & & & & & & \\
\hline \multirow[t]{2}{*}{ FDI } & 0,210 & 0,347 & 1,000 & & & & & & & & & & & \\
\hline & & & - & & & & & & & & & & & \\
\hline \multirow[t]{2}{*}{ Remit } & $-0,113$ & 0,027 & 0,116 & 1,000 & & & & & & & & & & \\
\hline & & & & - & & & & & & & & & & \\
\hline \multirow[t]{2}{*}{ Credit } & 0,210 & 0,347 & 1,000 & 0,116 & $-0,032$ & 1,000 & & & & & & & & \\
\hline & & & & - & & & & & & & & & & \\
\hline \multirow[t]{2}{*}{ Openness } & 0,361 & 0,673 & 0,498 & 0,204 & $-0,063$ & 0,498 & 1,000 & & & & & & & \\
\hline & & & - & - & & - & & & & & & & & \\
\hline \multirow[t]{2}{*}{ Inflation } & $-0,081$ & 0,118 & 0,006 & 0,089 & $-0,159$ & 0,006 & $-0,037$ & 1,000 & & & & & & \\
\hline & & - & & - & & & & & & & & & & \\
\hline \multirow[t]{2}{*}{ GFCF } & 0,145 & 0,199 & 0,182 & 0,064 & $-0,213$ & 0,182 & 0,097 & $-0,151$ & 1,000 & & & & & \\
\hline & & & & - & & & & & & & & & & \\
\hline \multirow[t]{2}{*}{ Totalrent } & 0,378 & 0,362 & 0,373 & 0,328 & 0,000 & 0,373 & 0,753 & 0,092 & 0,091 & 0,457 & 1,000 & & & \\
\hline & & - & - & & & - & & & - & - & & & & \\
\hline Polity & $-0,230$ & 0,282 & 0,153 & 0,419 & $-0,094$ & 0,153 & $-0,426$ & 0,025 & 0,061 & 0,220 & $-0,439$ & 0,093 & 0,401 & 1,000 \\
\hline
\end{tabular}

Source : Authors. 
Table A.3. Unit root tests

\begin{tabular}{|c|c|c|c|c|c|c|}
\hline & \multicolumn{2}{|c|}{ IPS_test } & \multicolumn{4}{|c|}{ Maddala\&Wu_test } \\
\hline & Constance & $\begin{array}{l}\text { constance } \\
\text { with trend }\end{array}$ & Decision & Constance & $\begin{array}{l}\text { constance } \\
\text { with trend }\end{array}$ & Decision \\
\hline Capitalgrowth & $-1,5074 *$ & & $\mathrm{I}(0)$ & $58.2701 * * *$ & 30.4316 & $\mathrm{I}(0)$ \\
\hline IFI & $0,5428 * * *$ & $\begin{array}{c}1,3995 \\
* * *\end{array}$ & $\mathrm{I}(0)$ & 22.5842 & 18.3238 & \\
\hline FDI & $-2,5230 * *$ & $\begin{array}{c}- \\
2,1028 *\end{array}$ & $\mathrm{I}(0)$ & $58.4559 * * *$ & $57.1405^{* * *}$ & $\mathrm{I}(0)$ \\
\hline Remittances & - & - & - & 22.7202 & $45.2570 * * *$ & $\mathrm{I}(0)$ \\
\hline Kaopen & - & - & - & 10.6853 & 3.1018 & - \\
\hline D.Credit & $-5,2214 * * *$ & $\begin{array}{c}- \\
3,27 * * *\end{array}$ & $\mathrm{I}(0)$ & $92.1768 * * *$ & $67.7099 * * *$ & $\mathrm{I}(0)$ \\
\hline D.Openness & $-7,1674 * * *$ & $\begin{array}{c}- \\
6,19 * * *\end{array}$ & $\mathrm{I}(0)$ & $137.2251 * * *$ & $131.1879 * * *$ & $\mathrm{I}(0)$ \\
\hline Inflation & $11,9071 * * *$ & & $\mathrm{I}(0)$ & $307.6923 * * *$ & $182.1018 * * *$ & $\mathrm{I}(0)$ \\
\hline GFCF & $-2,7996 * * *$ & $-1,36 * * *$ & $\mathrm{I}(0)$ & $73.4584 * * *$ & $56.3307 * * *$ & $\mathrm{I}(0)$ \\
\hline $\mathrm{HCI}$ & & & $\mathrm{I}(0)$ & $54.0264 * *$ & $64.0407 * * *$ & $\mathrm{I}(0)$ \\
\hline D.Totalrent & $-8.6231 * * *$ & $\begin{array}{c}- \\
7.4972 * * *\end{array}$ & $\mathrm{I}(0)$ & $166.4975 * * *$ & $148.2000 * * *$ & $\mathrm{I}(0)$ \\
\hline Govexp & $-2.7137 * * *$ & $\begin{array}{c}- \\
2.5517 * * *\end{array}$ & $\mathrm{I}(0)$ & $83.0816^{* * *}$ & $70.3024 * * *$ & $\mathrm{I}(0)$ \\
\hline Corruption & $-1.4354^{*}$ & $7.7336 * * *$ & $\mathrm{I}(0)$ & 39.5888 & 24.0054 & - \\
\hline Polity & - & - & - & $46.5121 * *$ & 34.4917 & $\mathrm{I}(0)$ \\
\hline
\end{tabular}


Note: $* * *, * *, *$ indicate significance at $1 \%, 5 \%, 10 \%$ level.

Source : Authors.

Table A.4. Cointegration test

\begin{tabular}{lll}
\hline Pedroni test & & p- \\
\hline Modified Phillips-Perron t & Statistic & value \\
Phillips-Perron t & 4.6715 & 0.0000 \\
AugmentedDickey-Fuller t & 0.4545 & 0.3248 \\
\hline & & \\
\hline Westerlund test & 1.6851 & 0.0460 \\
\hline & & \\
Variance ratio & & \\
& 4.0910 & 0.0000 \\
\hline Source : Authors & &
\end{tabular}

